\title{
Development of Desktop-based River Basin Monitoring and Flood Warning System for Malaysia
}

\author{
A.F. Ismail, Nor Bazilah Bopi, K. Badron, Suriza A. Zabidi and Ismail Maszlan ${ }^{2}$ \\ Electrical and Computer Engineering Department \\ International Islamic University Malaysia \\ bazilah_2307@yahoo.com,af_ismail@iium.edu.my,khairayu@iium.edu.my, \\ suriza@iium.edu.my
}

\begin{abstract}
Floods have been one of the major disasters that occur in most countries all over the world. A flood can wreck homes, infrastructures, buildings, properties and even lead to the spread of diseases such as cholera and dengue. The river basin monitoring and flood warning system was developed based on a main objective of to develop an interactive, informative and user-friendly monitoring and warning system which can act as an information channel for the related authorities and experts to take adequate actions in order to reduce the risk of hazards and loss due to floods. Information such as river stage and rainfall rate at river basin as well as tidal forecasts are important in predicting the floods. This system aimed to be a useful and reliable flood monitoring and warning system which serves as a one stop information center by providing those essential information. This first prototype was built using Visual Basic as the main tool and other open-source software and tools which include QGIS and PostgreSQL.
\end{abstract}

Keywords: Flood, River Basin, Rainfall Rate, Real-time Monitoring

\section{Introduction}

Floods have been one of the major disasters that occur in most countries all over the world. In most cases, floods occur due to continuous heavy rains, which result in excessive rain water to overflow the river banks and inundate the normally dry areas. Other factors, such as uncontrolled deforestation and high tide phenomenon contribute in worsening the event. Significant deforestation may lead to rapid movement of the flood peak and generate bigger risks to the populated areas in short period of time. High tide phenomenon, or called perigean spring tide can prevent the huge amount of water travel the headwaters to enter the river mouth, thus forcing the water to flood the dry lands [1].

A flood can wreck homes, infrastructures, buildings, crops, livestock, public goods, roads and railways. Not only that, floods can also contribute to several diseases such as cholera, diarrhea and dengue. In Malaysia, floods usually occur during the northeast monsoon which takes place in early November and ends in March every year [2]. The affected areas include western Sarawak, east Johor and east coast states, which are Kelantan Terengganu and Pahang. All of these areas receive heavy rainfall during the monsoon that can lead to severe flood.

Out of all states in Malaysia, Kelantan is chosen as the study area of this research. As one of the states in the east coast region, Kelantan has experienced numerous flood events. The latest severe flood to occur in the state was in December 2014, where over 150,000 victims needed to be evacuated from their settlements [3]. The effects were devastated. Victims lost their, houses, vehicles and properties while many of the state's infrastructures and buildings were destroyed. It was assumed that the state suffered from the total loss of over RM200 millions [4]. The catastrophe was due to unusual heavy rains caused by the north east monsoon and the spring tide which took place right after the rains 
[5]. This tragedy has triggered the urge to develop a GUI (Graphic User Interface) to display all of the required information as well as generate warnings when there are possibilities of flood occurrence for the state of Kelantan.

Since the flood is almost an annual occurrence, it is important to monitor the real-time data such as river stage or river water level and rainfall rate in order to decide any necessary actions to reduce the risk of hazards and loss due to the flood. Besides, the tidal forecast is also crucial in providing better warnings of flood occurrences. Time management is essential in confronting the occurrence of disasters. Proper solutions and decisions need to be done in a short period of time so that required actions can be completed in time before the disasters happen. A user-friendly warning system is needed with sufficient information such as real-time data of river stage and rainfall rate, tidal forecast, and a list of hydrological stations, along with the details of each station in the state of Kelantan.

Numerous studies and researches about flood monitoring and warning system have been conducted around the world. Combining hydrological model and GIS, Shaohong and Pengxiao have developed a real-time flood monitoring system using ArcGIS software [6]. Wireless sensor network system is on one of the methods used in developing flood monitoring [7-8]. In Bangladesh, a flash flood monitoring system, which consists of a hardware module, data collection software module and a web monitoring console module has been implemented [7]. [9] and [10] have conducted researches on flood monitoring and assessment using GIS and remote sensing techniques.

This paper is organized as follows; section 1 explains briefly about the floods; its definition, causes and effects as well as the overview of the research while in section 2, data collection process for the proposed system is described. Section 3 and section 4 discuss on the research methodology and results, respectively. The paper is concluded in section 5 .

\section{Data Collection}

In Malaysia, water level and rainfall stations are governed by Malaysian Department of Irrigation and Drainage (DID). Water level, or river stage at river basin and rainfall rate are measured using several types of sensors and equipment such as manual stick gauge, submersible-type pressure sensor as well as float and stilling well for river stage measurement whereas manual rain gauge and tipping bucket are used to collect rainfall data [11]. The data are then collected by data logger at each station. The transmission of the data to the master server is done using telemetry systems. The real-time data are updated to DID website in hourly basis. If warnings are detected, the data will be update more frequently, as in 30 minutes or 15 minutes intervals.

Since this research focuses in developing GUI, the data from the sites are collected from the DID website, InfoBanjir Primary [12]. It provides real-time data of river stage and rainfall rate for available online stations around the country. For the purpose of this research, river stage and rainfall rate tables for 25 telemetric stations in Kelantan are retrieved via Microsoft Excel. The tables consist of station IDs, names, time of last update, current values of river stage and rainfall as well as other information. The information is then manipulated to generate more useful information. The information is organized according to its station before it is stored in the database for future reference. Table 1 shows a list of Kelantan hydrological stations. 
Table 1. List of Kelantan Hydrological Stations

\begin{tabular}{|c|c|c|c|c|c|}
\hline No. & Station & Type & District & River & River Basin \\
\hline 1 & Air Bol & $\begin{array}{l}\text { Rainfall and } \\
\text { water level } \\
\text { station }\end{array}$ & Jeli & Sg. Pergau & Sg. Pergau \\
\hline 2 & Air Mulih & $\begin{array}{l}\text { Rainfall and } \\
\text { water level } \\
\text { station }\end{array}$ & Pasir Mas & Sg. Kelantan & Sg. Kelantan \\
\hline 3 & Bachok & Rainfall Station & Bachok & Sg. Kemasin & Sg. Kelantan \\
\hline 4 & Batu 13 Jeli & Rainfall Station & Jeli & Sg. Pergau & Sg. Pergau \\
\hline 5 & Dabong & Rainfall Station & Kuala Krai & Sg. Galas & Sg. Kelantan \\
\hline 6 & $\begin{array}{l}\text { Empangan Bukit } \\
\text { Kwong }\end{array}$ & $\begin{array}{l}\text { Rainfall and } \\
\text { water level } \\
\text { station }\end{array}$ & Pasir Mas & & Sg. Golok \\
\hline 7 & Gua Musang & Rainfall Station & Gua Musang & Sg. Galas & Sg. Kelantan \\
\hline 8 & Gunung Gagau 1 & Rainfall Station & Gua Musang & Sg. Gagau & Sg. Kelantan \\
\hline 9 & Gunung Gagau 2 & Rainfall Station & Gua Musang & Sg. Gagau & Sg, Kelantan \\
\hline 10 & Jeti Kastam & $\begin{array}{l}\text { Rainfall and } \\
\text { water level } \\
\text { station }\end{array}$ & Kota Bharu & Sg. Kelantan & Sg. Kelantan \\
\hline 11 & Kg. Aring & $\begin{array}{l}\text { Rainfall and } \\
\text { water level } \\
\text { station }\end{array}$ & Gua Musang & Sg. Aring & Sg. Kelantan \\
\hline 12 & Kg. Jeli & Rainfall station & Jeli & Sg. Pergau & Sg. Kelantan \\
\hline 13 & Kg. Jenob & $\begin{array}{l}\text { Rainfall and } \\
\text { water level } \\
\text { station } \\
\end{array}$ & Tanah Merah & Sg. Golok & Sg. Golok \\
\hline 14 & Kg. Kuala Jambu & $\begin{array}{l}\text { Rainfall and } \\
\text { water level } \\
\text { station }\end{array}$ & Tumpat & Sg. Golok & Sg. Golok \\
\hline 15 & Kg. Laloh & Rainfall station & Kuala Krai & Sg. Lebir & Sg. Kelantan \\
\hline 16 & Kg. Lembaga & $\begin{array}{l}\text { Water level } \\
\text { station }\end{array}$ & Gua Musang & Sg. Galas & Sg. Kelantan \\
\hline 17 & Kuala Koh & $\begin{array}{l}\text { Rainfall and } \\
\text { water level } \\
\text { station }\end{array}$ & Kuala Krai & Sg. Lebir & Sg. Kelantan \\
\hline 18 & Kuala Krai & $\begin{array}{l}\text { Rainfall and } \\
\text { water level } \\
\text { station }\end{array}$ & Kuala Krai & Sg. Kelantan & Sg. Kelantan \\
\hline 19 & Kusial & $\begin{array}{l}\text { Rainfall and } \\
\text { water level } \\
\text { station }\end{array}$ & Tanah Merah & Sg. Kelantan & Sg. Kelantan \\
\hline 20 & Limau Kasturi & Rainfall station & Gua Musang & Sg. Galas & Sg. Kelantan \\
\hline 21 & Lojing & Rainfall station & Gua Musang & & Sg. Kelantan \\
\hline 22 & Pasir Puteh & $\begin{array}{l}\text { Rainfall and } \\
\text { water level } \\
\text { station }\end{array}$ & Pasir Puteh & Sg. Semerak & Sg. Semerak \\
\hline 23 & Rantau Panjang & $\begin{array}{l}\text { Rainfall and } \\
\text { water level } \\
\text { station }\end{array}$ & Pasir Mas & Sg. Golok & Sg. Golok \\
\hline
\end{tabular}




\begin{tabular}{|l|l|l|l|l|l|}
\hline $\mathbf{2 4}$ & Tualang & $\begin{array}{l}\text { Rainfall and } \\
\text { water level } \\
\text { station }\end{array}$ & Kuala Krai & Sg. Lebir & Sg. Kelantan \\
\hline $\mathbf{2 5}$ & Tumpat & Rainfall station & Tumpat & Sg. Kelantan & Sg. Kelantan \\
\hline
\end{tabular}

\section{Methodology}

Figure 1 shows a flowchart that was used as the guideline for the system development.

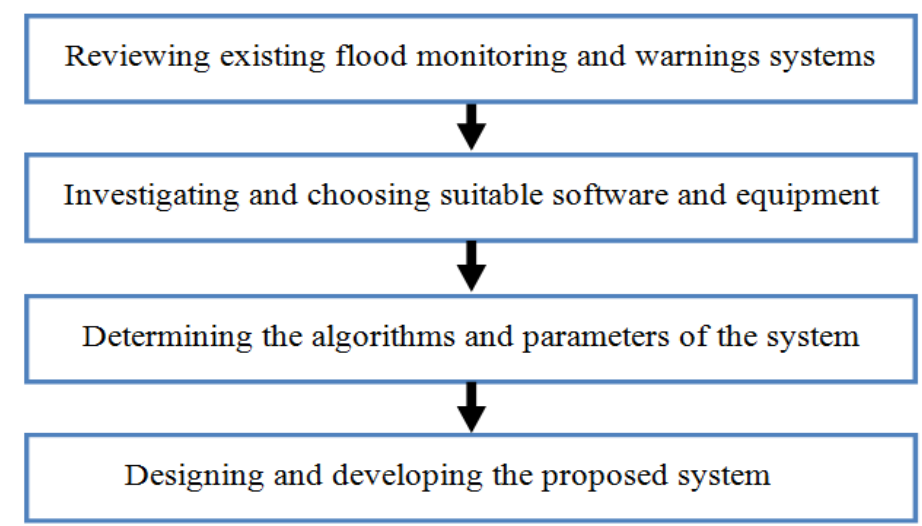

Figure 1. Research Flowchart

All the activities conducted in this research were summarized in the research workflow, as shown in Figure 2. The works were categorized into four phases. The first phase was the preliminary phase, where the user needs and data requirement were evaluated and determined. The database for this system was also designed in this phase. The second phase, the development phase include processes such as the development of the proposed database, collection of data as well as the design and development of the proposed system. The system was evaluated and modified to meet the user needs and requirement in the evaluation phase. If the system was required to be redesigned, the progress returned to the previous phase and the system will be evaluated again until it satisfied the entire requirement. Finally, the system entered the implementation phase, in which the system was implemented and ready to be used. System maintenance process is also included in this phase.

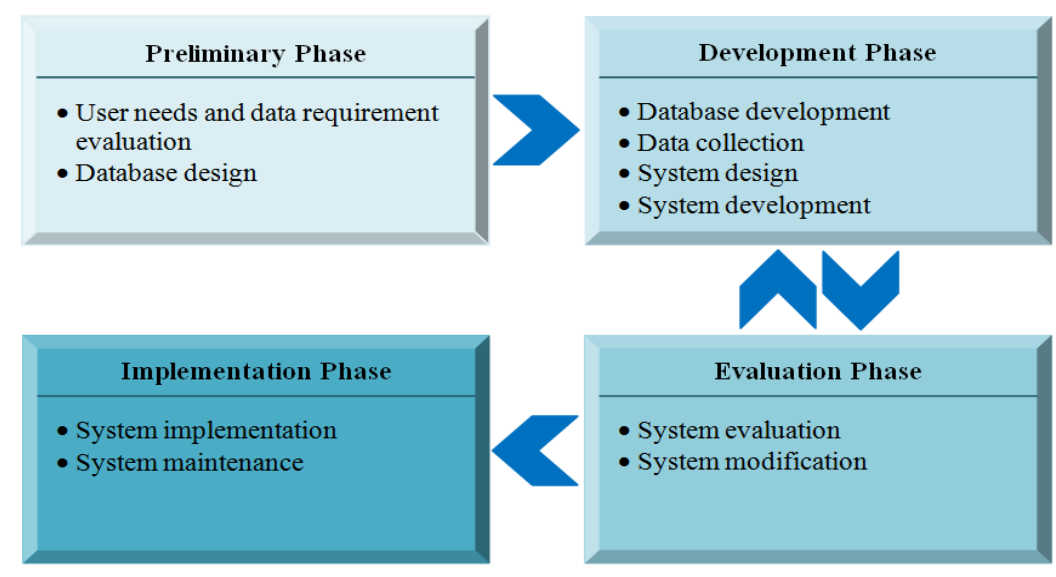

Figure 2. Research Workflow 
The prototype of River Basin Monitoring and Flood Monitoring System was built using Visual Basic programming language in Visual Studio Community 2015 as the main tool. Open-source QGIS 2.12 (Quantum Geographic Information System) software was used to generate Kelantan map, along with the locations of 25 telemetric stations and open-source PostgreSQL 9.3 database acted as the system database. Other tools include Microsoft Excel and Adobe Photoshop.

\section{Results and discussion}

The first prototype of desktop-based application, named 'Kelantan River Basin and Flood Monitoring System' was developed. The login page of the system is shown in Figure 3. The access to the system is limited to two levels of users; administrators and registered users. Only the administrators are authorized to register new users, provide username and passwords to them as well as edit and remove existing users.

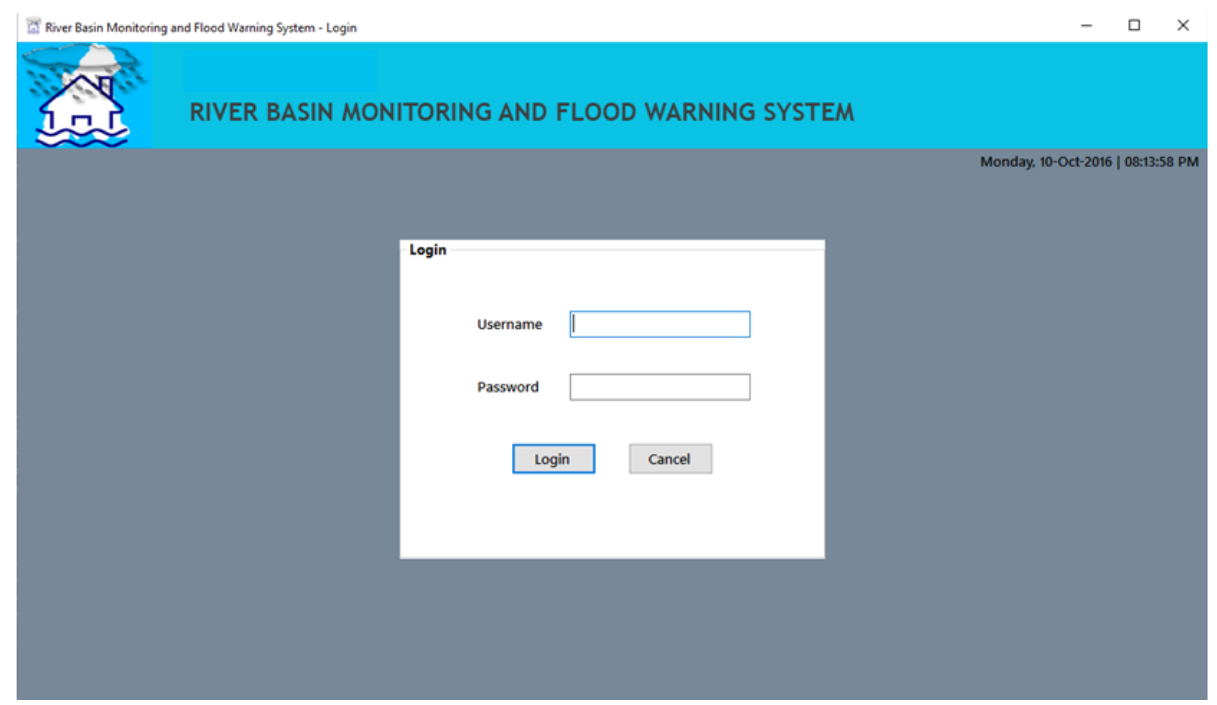

Figure 3. The Application's Login Page

The main page of the application shows the markers indicating the telemetric stations on the map of Kelantan as in Figure 4. The stations are categorized into three categories; rainfall stations, water level stations and rainfall and water level stations. Info windows which consists of information such as GPS coordinates of each station, will appear when the marker is clicked. On top of the map, menus such as 'Water Level Data', Rainfall Data', 'Tidal Forecasts' and 'Alert', were presented in the form of buttons. Upon logging in, the 'Alert' button will blink if there are warnings issued, to directly notify the users without viewing the 'Alert' page. 


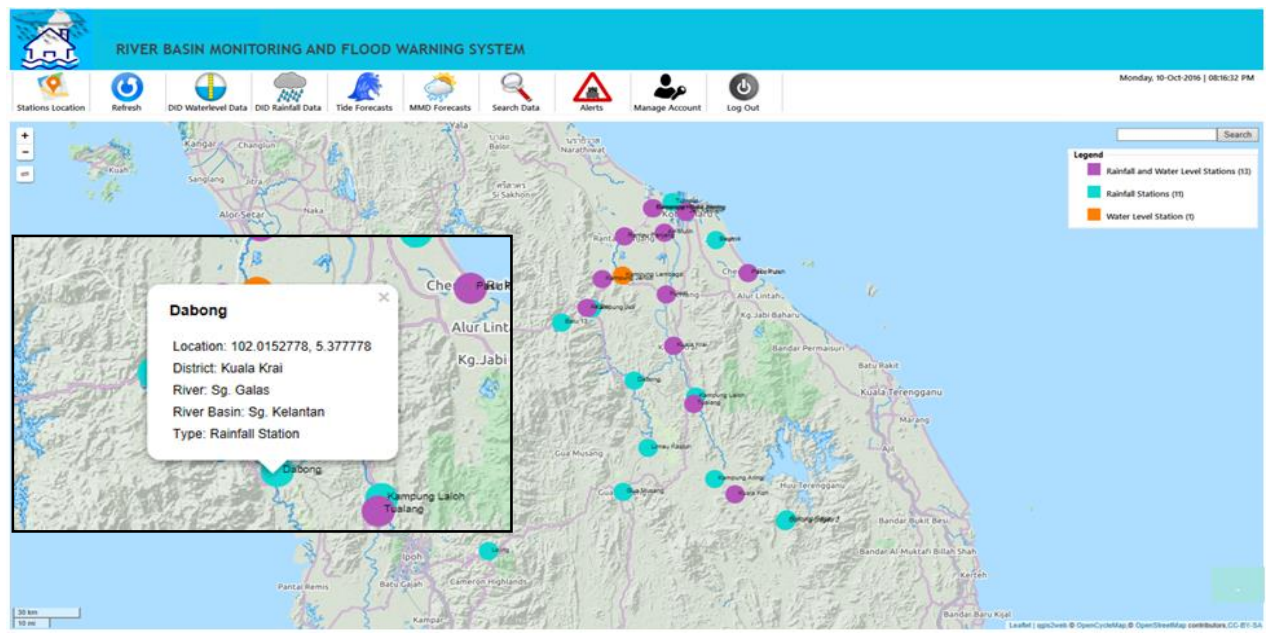

Figure 4. Hydrological Stations on Kelantan Map Shown In the Main Page

In Figure 5, the refined table of water level data is shown with some additional information such as 'River Level since Last Update' and 'Status'. The alert, warning and danger levels of river of each station differ, depending on the width and depth of the river section. The 'status' column will show 'Normal' status when the river level stays under the alert level. Once the river water rises and exceeds the alert level, 'Alert' status will be issued. When the river water surpasses the warning level and danger level, 'Warning' and 'Danger' status are shown, respectively.

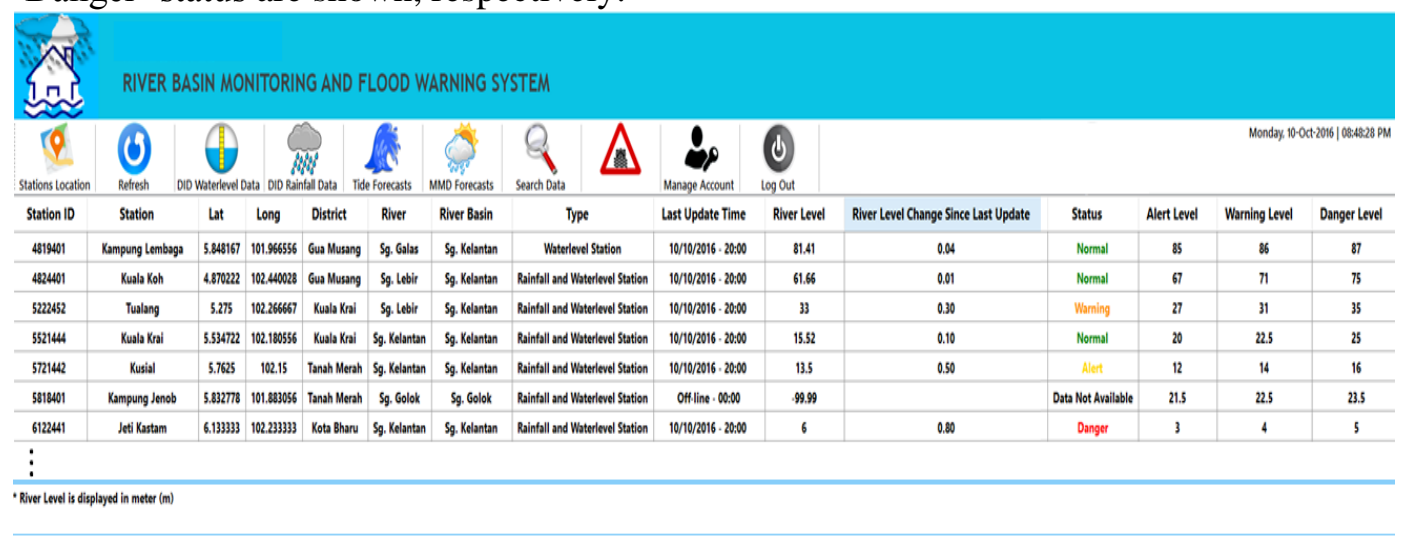

Figure 5. Water Level Data

Figure 6 shows the table for DID rainfall data. Status of rainfall changes according to the amount of rainfall rate measured since midnight daily. The rainfall intensity is categorized in four categories, as predetermined by DID. When the rainfall rate is in range of $1-10 \mathrm{~mm} / \mathrm{h}$, the rain is considered as light. Moderate and heavy rains are issued when the rainfall rate is in the range of $11-30 \mathrm{~mm} / \mathrm{h}$ and $31-60 \mathrm{~mm} / \mathrm{h}$, respectively. If the rainfall rate exceeds $60 \mathrm{~mm} / \mathrm{h}$, it is considered as extreme rain. Warnings will be published in the 'Alerts' page when heavy and extreme rain occur. Information such as status and amount of rainfall rate, as well as station's name and its district are mentioned in the rainfall warning, as shown in Figure 7. Likewise, warnings for river stage will be dispensed when the river water surpasses warning, alert and danger level. 


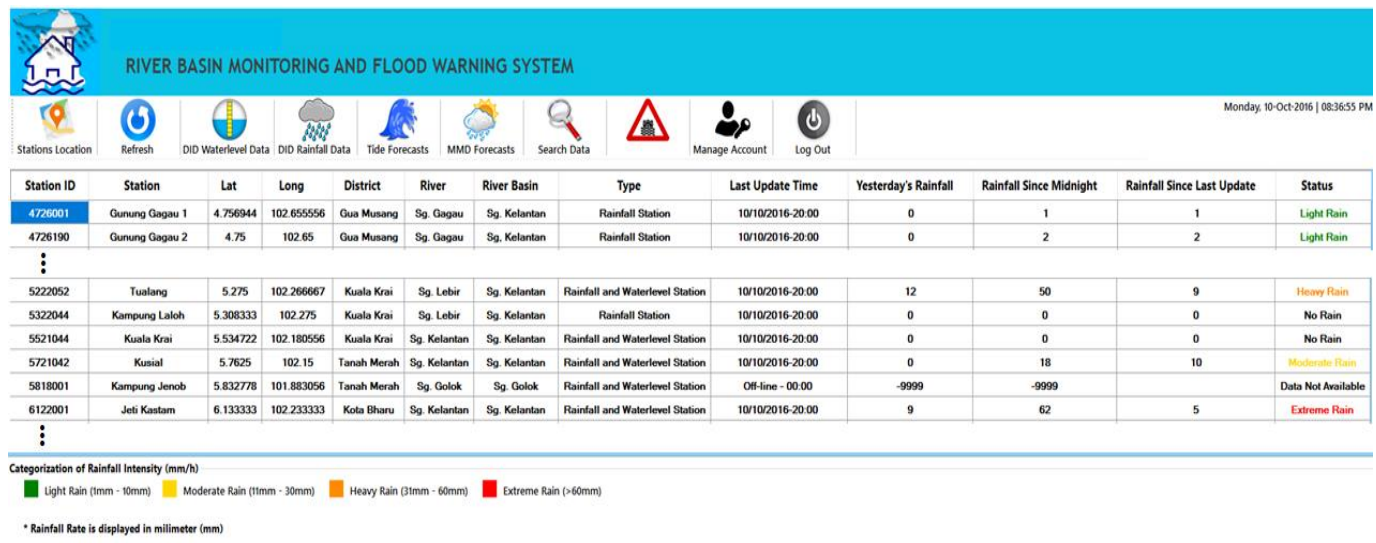

Figure 6. Rainfall Rate Data

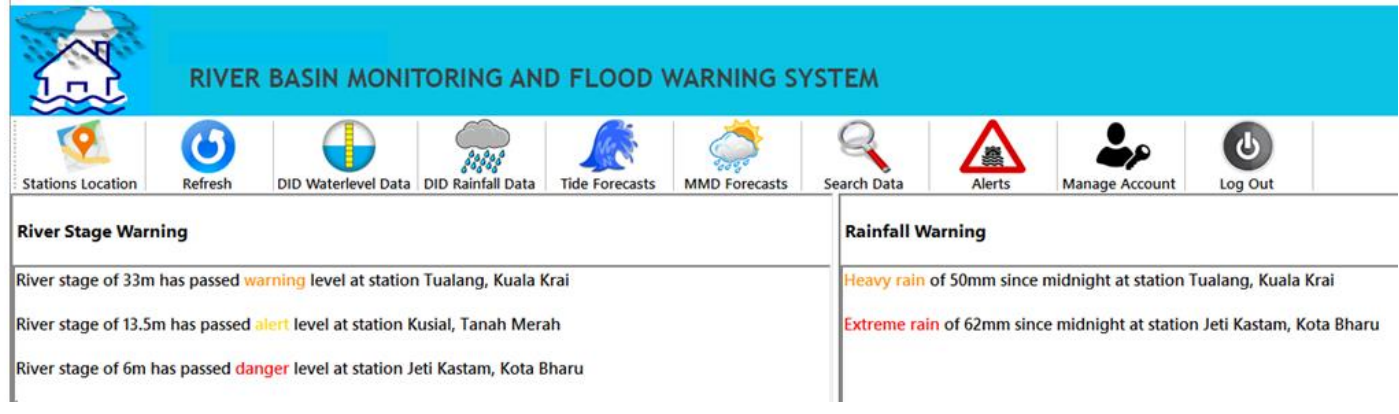

Figure 7. Warnings Issued In 'Alerts' Page

In this application, users are also supplied with tidal forecast from Geting station in Tumpat, Kelantan for Kelantan waters. Presented in two tables, users are able to view an hourly tidal prediction table and another table shows the times and heights of high and low tides. Both tables provide tidal predictions up to seven days. Figure 8 shows the tidal prediction tables.

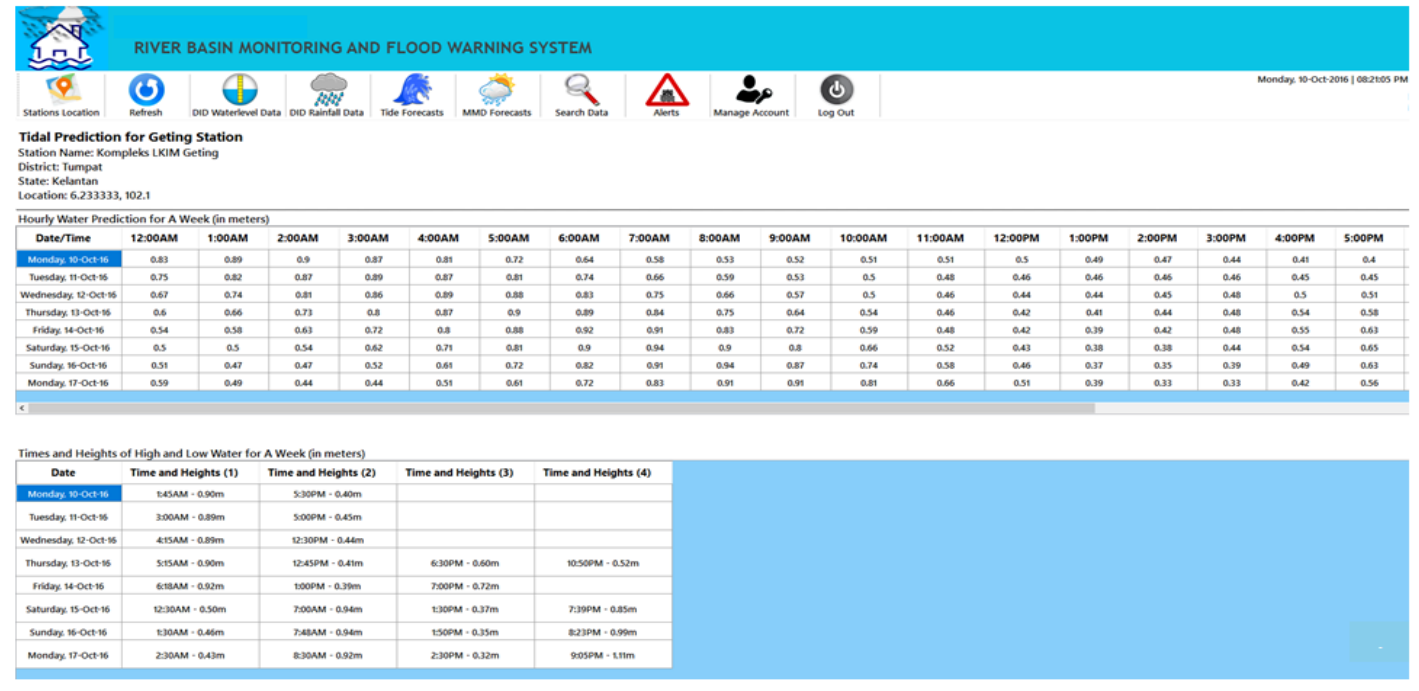

Figure 8. Tidal Forecasts Tables 
This prototype is limited to displaying data without having any graphical analysis ability. It is only operational when there is internet connection and as long as the data source, namely the DID website is available. However, the main objective of this research, which is to develop an interactive, informative and user-friendly GUI has been achieved.

\section{Conclusion}

The first, trial version of River Basin Monitoring and Flood Warning System is presented in this paper. Flood is a common natural disaster, but it can be dreadful if there are no actions taken or warnings issued before the event occurs. This system provides an interactive and user-friendly GUI with reliable and useful information to serve as the guidelines for the related authorities and experts to take necessary decisions and actions so that the hazards risk can be minimized. Based on the recent flood history, Kelantan has been chosen as the study area for this research. This system consists of rainfall and water level data from 25 telemetric stations in Kelantan as well as tidal prediction tables for Kelantan waters. By using powerful open-source software and tools, a reliable and interactive system has been developed with minimal cost. As the technology keep growing and expanding, the proposed system is compliant to any necessary changes and improvement.

\section{Acknowledgements}

This research was financially supported by Research Management Centre of International Islamic University of Malaysia (IIUM).

\section{References}

[1] N.B. Bopi, A.F. Ismail, S.A. Zabidi and M.K. Hasan, Indian Journal of Science and Technology. Development of a Rainfall Rate Monitoring System for Malaysia. 9, 28 (2016)

[2] N.B. Bopi, A.F. Ismail, S.A. Zabidi and M.K. Hasan, International Journal of u-and e-Service, Science and Technology. Development of a River Basin Monitoring System for Malaysia. 9, 7 (2016), pp. 349360.

[3] Banjir di Kelantan semakin buruk, mangsa di enam negeri lebih 225,000. http://www.astroawani.com/berita-banjir/banjir-di-kelantan-semakin-buruk-mangsa-di-enam-negerilebih-225-000-51137. Astro Awani. Retrieved 2016-09-20.

[4] Lebih RM200 juta kerugian banjir di Kelantan. http://www.astroawani.com/videos/show/awani-745/lebih-rm200-juta-kerugian-banjir-di-kelantan-47622. Astro Awani. Retrieved 2016-09-20.

[5] Fenomena 'new moon' burukkan keadaan banjir. http://www.utusan.com.my/berita/nasional/fenomena8216-new-moon-8217-burukkan-keadaan-banjir-1.40028. Utusan Online. Retrieved 2016-09-20.

[6] S. Shaohong and C. Pengxiao, A Real-time Flood Monitoring System Based on GIS and Hydrological Model. 2010 International Conference on Environmental Science and Information Application Technology (ESIAT), IEEE (2010), Vol. 1, pp. 605-608.

[7] M. A. Islam, T. Islam, M. A. Syrus and N. Ahmed, Implementation of Flash Flood Monitoring System Based on Wireless Sensor Network in Bangladesh, In 3rd International Conference on Informatics, Electronics \& Vision, (2014).

[8] S. Shukla, and G. Pandey, , International Journal of Computer Science and Information Technology. To Design an Architectural Model for Flood Monitoring Using Wireless Sensor Network System, Vol. 5, (2014), pp.502-507.

[9] M. Haq, M. Akhtar, S. Muhammad, S. Paras, and J. Rahmatullah, The Egyptian Journal of Remote Sensing and Space Science. Techniques of Remote Sensing and GIS for Flood Monitoring and Damage Assessment: A Case Study of Sindh Province, Pakistan, 15, 2 (2012), pp.135-141.

[10] A. T. Jeyaseelan, Satellite Remote Sensing and GIS Applications in Agricultural Meteorology. Droughts \& Floods Assessment and Monitoring Using Remote Sensing and GIS, (2003), pp. 291-313.

[11] DID Manual, Volume 4 - Hydrology and Water Resources, Department of Irrigation and Drainage, Government of Malaysia, Kuala Lumpur, (2009).

[12] Kelantan. http://infobanjir2.water.gov.my/waterlevel_page.cfm?state=KEL. InfoBanjir Primary. Retrieved 2016-02-29. 


\section{Authors}

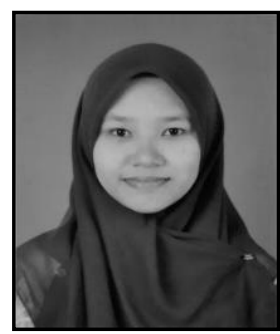

Nor Bazilah Bopi, she currently pursuing her MSc studies at International Islamic University of Malaysia (IIUM) in Computer and Information Engineering. She completed her bachelor degree studies in 2014 at IIUM in Electronics-Computer and Information. Her research interests are in open-source software development, wireless communication and computer networks and communications.

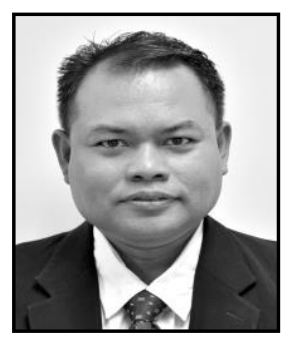

Ahmad Fadzil Ismail, he currently an Associate Professor at Department of Electrical and Computer Engineering, Faculty of Engineering, International Islamic University Malaysia (IIUM). $\mathrm{He}$ completed his bachelor degree studies in Electrical Engineering at Gannon University, Pennsylvania, USA with Cum Laude Latin honors. He holds MSc and $\mathrm{PhD}$ from University of Essex, UK and University of Bath, UK, respectively. He is registered with Board of Engineering Malaysia as a Professional Engineer and also a senior member of IEEE. His research interests include development of active and passive target tracking algorithms, radio frequency and wireless systems and microwave and milimetrewave technology.

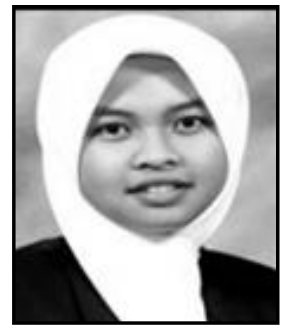

Khairayu Badron, she obtained her BEng, MSc and Ph.D from International Islamic University Malaysia (IIUM) in 2007, 2011 and 2016 respectively. She is currently one of the Assistant Professor of Faculty of Engineering, IIUM. Her research areas are in Radar and Radiometry research, quantifying propagation effects on microwave and millimeter links. Khairayu is a member of IEM, BEM and IEEE. She has published and co-authored more than fifty papers in International Journals as well as Conferences on subjects relating to rain attenuation in the tropical regions.

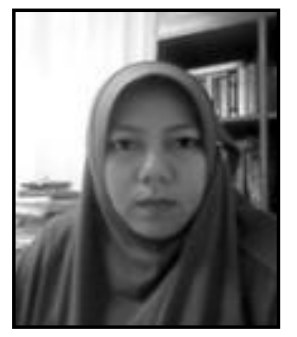

Suriza Ahmad Zabidi, she obtained her PhD in Engineering at the Faculty of Engineering, International Islamic University Malaysia. She completed her MSc in the area of Computer and Information Engineering in 2003 from the same university and B.Eng in Electrical Engineering from George Washington University. She is now an Assistant Professor at Faculty of Engineering, International Islamic University Malaysia. She is a member of Board of Engineering Malaysia and also a member of the IEEE. Her current research interest focus on Free Space Optic, Optical Wireless, Visible Light Communication and Wireless Communication Application. 
International Journal of $u-$ and e- Service, Science and Technology Vol. 10, No.3 (2017) 